\title{
Implementation of 3D Animation for Identification of Coral Reefs Based on Android Mobile Application
}

\author{
Moh Alifuddin', Sitti Zuhriyah ${ }^{2}$, Pujianti Wahyuningsih $^{3}$, Billy Eden William Asrul ${ }^{4}$ \\ \{alifuddin@handayani.ac.id ${ }^{1}$, zuhriyah@handayani.ac.id ${ }^{2}$, uji.wahyuningsih@gmail.com³ \\ bewagabriel@ymail.com ${ }^{4}$ \} \\ 1,2,3,4 STMIK Handayani, Adhyaksa Baru Street No 1. Makassar, Indonesia
}

\begin{abstract}
Coral reefs are underwater ecosystems that consist of a group of coral animals that form the structure of the calcium carbonate, a kind of limestone. Coral reef ecosystems have high productivity and diversity of fauna species. This study aim is to design the Android-based application for identifying the types and species of coral reefs. Android-based application for determining types of coral reef is designed structurally consisting of design models, i.e. flowchart, use case diagram, activity diagram, sequence diagram, class diagram and output design. The research method used to design the identification of coral types is $3 \mathrm{D}$ animation technique, action research-based on system analysis, application design, implementation, and testing. The data in this study was obtained by using observation, interview and documentation. The research result is the android application can identify the types of coral reefs in the form of 3D images, text, sound and animation.
\end{abstract}

Keywords: 3D Animation, Coral Reefs, Android Mobile Application.

\section{Introduction}

Indonesia is a rich country of natural resources. One of the is marine resources. According to UNCLOS 1982, Indonesia has 5.9 million Km2 widths of a marine area [1] and its maritime wealth such as coral reef [2]. The coral reef is a unique community of marine which is formed by biological activity. It also has significant value and meaning both socially, economically and cultural aspects because nearly a third of Indonesian who live in the coastal area depend on their life of shallow sea fisheries [2],[3].

Several researchers have applied the research of coral reef. One of them is the application of coral reef encyclopedia learning based on multimedia [4]. The coral reef has identified by the image of Landsat 8 which has applied on waters of the southern part of the islands in Sumenep [5]. This research also can detect the quality of coral reefs. Furthermore, a study of coral damage detection has applied on coastal waters Molotabu Province Gorontalo [6], these research can detect some coral damage by explosives of catching fish.

The importance of knowledge about coral reefs and the introduction to society becomes the motivation for the researcher to build a 3D animation in mobile android so we can introduce the coral to the community easier. The 3D application is made interactively and equipped by sound and text in explaining the coral kinds which want to study. 


\section{Research Method}

\subsection{System analysis}

The first step to develop a program is to analyse the ongoing system. Generally, society can learn dan recognise the coral reef conventionally by article, diving or snorkelling, and reading the books. The figure below is an ongoing use case in the community to find information about the coral reef.

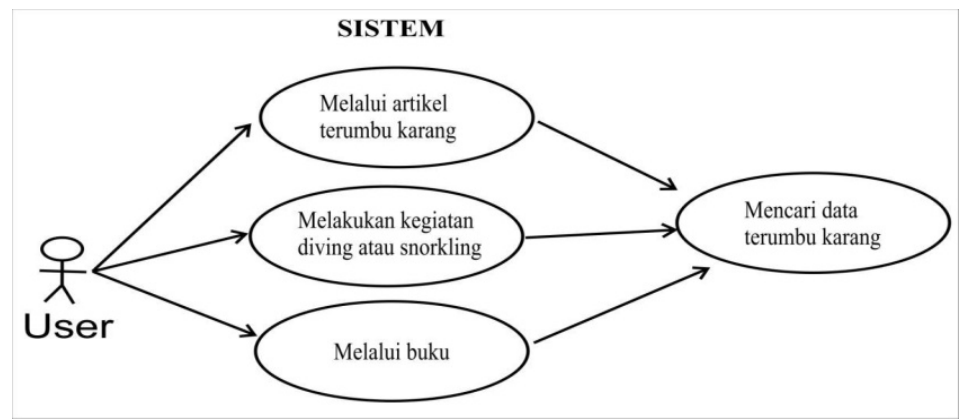

Fig.1. Usecase system

According to the information above, we can see the recognition system of coral reef is not useful because it is conventional. The use of 3D technology on the Android mobile will be beneficial for the community to learn and recognise the coral reef because of the $3 \mathrm{D}$ technology very interactive and easy to use in the mobile android.

\subsection{Data Collection Technique}

The technique of data collecting in this research has three steps, namely :

a. Observation

The researchers collect data by observing to research object directly to gain data or description and explanation of the system.

b. Interview

Data are collected by interviewing or doing direct question and answer to responsible agency and can give information and data about the coral reef. The data are information about the introduction, kinds, and the characteristic of coral reef.

c. Documentation

The researchers collect data by learning the literature, such as books, articles, documents or files, and another guideline which can support the research. Otherside, pictures and photographs of coral reefs are needed as a reference of information to build the application. 


\section{Result and Discussion}

\subsection{Running System}

According to the running system of analyses, the researcher gives a solving problem by application design to introduce coral reefs base on android so the people can learn coral reefs by accessing this application. The suggested system model can be seen in figure 2

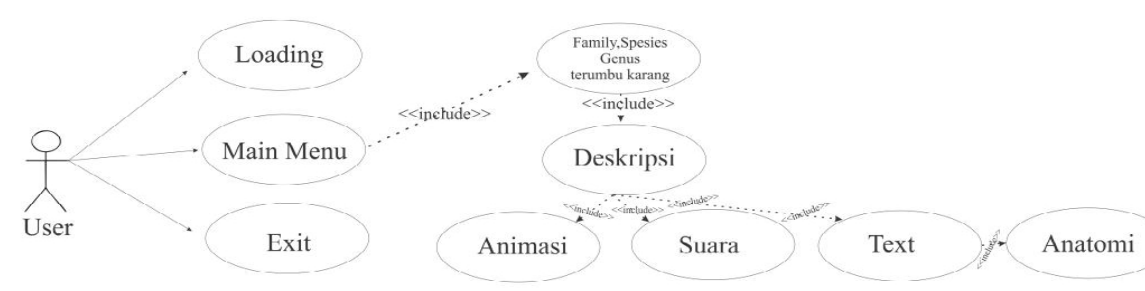

Fig.2. Suggested usecase

\subsection{Activity diagram}

On the activity diagram, it describes how the process of the application is. The first step to run the app is the user opens the application on mobile android, then the menu page will be shown which consists of a choice MENU and QUIT. On the menu page, there is the choice of information of kind coral reef based on the name. The user can choose one name coral reef to see and learn in 3D animation. If the user selects the QUIT button, the application will quit, and the process will ends. The figure below is the activity diagram of this research.

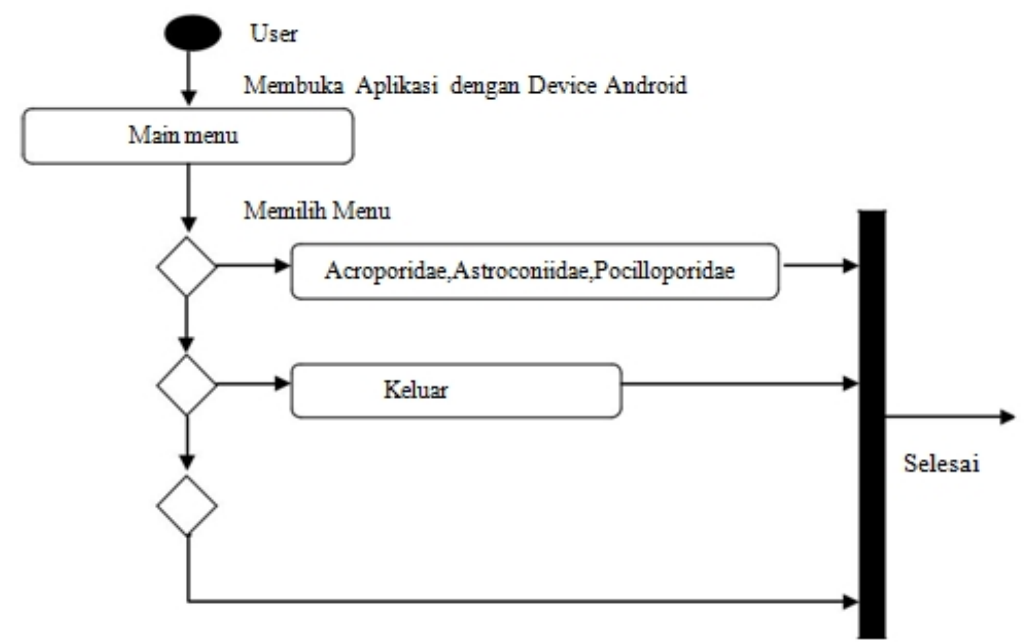

Fig. 3. Activity diagram 


\subsection{Class diagram}

On the class diagram, there is a relation between class and attribute. Every class and attributes will connect each other to relate and show the information based on every course. This figure below is a class diagram of application.

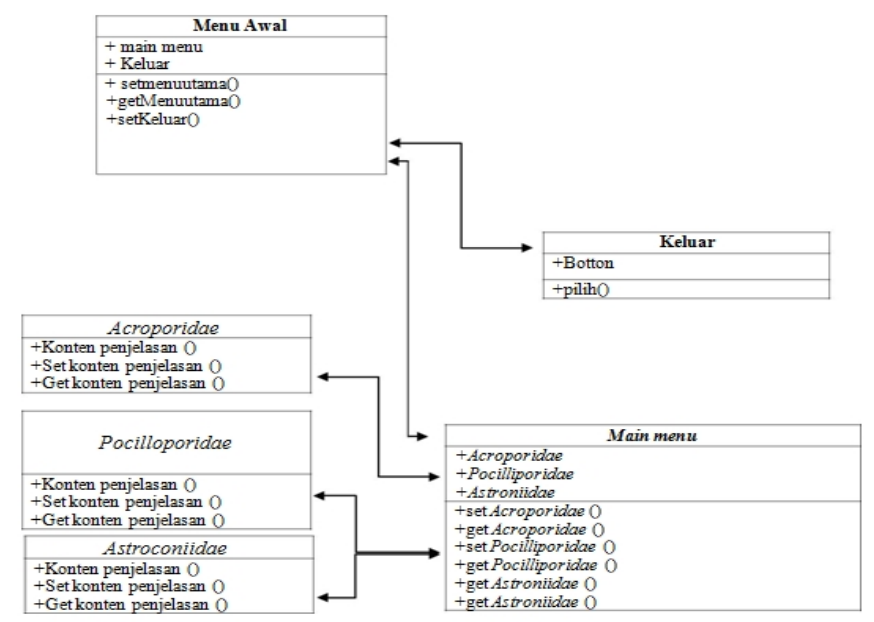

Fig. 4. Class diagram

\subsection{Algorithm Implementation}

On the implemented algorithm, in the application have several buttons that can select by the user to run the application.

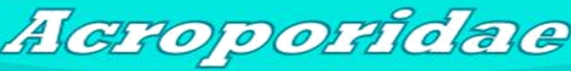

Fig. 5. Display of acroporidac

The program source is :

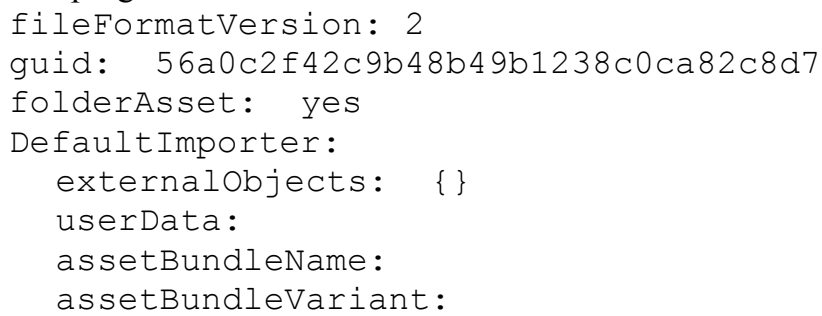

Beside the buttons, there is loading display to give information that the user should wait for application processing. The picture below is loading process before entering the main menu 


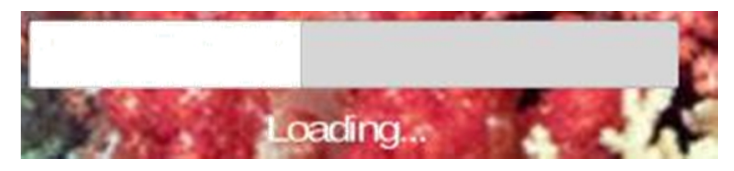

Fig. 6. Display of loading

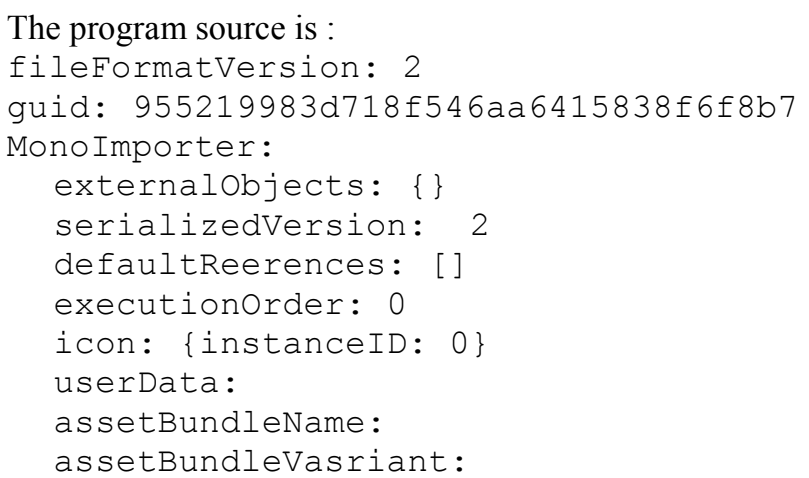

\subsection{Implementation system}

When the user operates the application of coral reef recognition for the first time, the display will show main page with "Main Menu" and "Exit" button. The figure below shows the display of main menu while user opens the application.

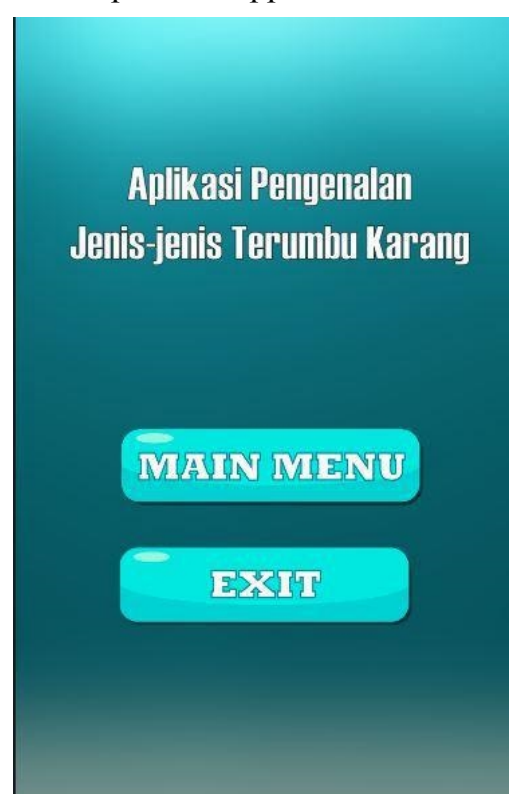

Fig. 7. Main View 
If the user pushes button "Main Menu", the page to choose kinds of coral reef will open, the user can push the button according to the name of coral which you want to see. When using push the button "Acroporidae", the user can see some kinds of coral such as Acroporacaroliniana, Anacroporareticulate, Astropora acellata, Matipora danae, and Acropora melipora. The figure below shows the main page of Acroporidae

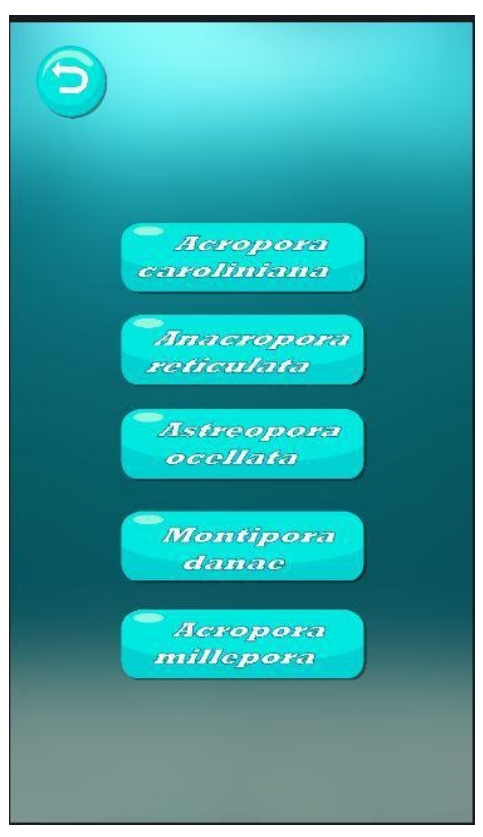

Fig.8. Display of Acroporidae page

The user can push one of a button to see the species of coral reef in detail with a 3D display. When user push button "Acropora melipora", the new page will be opened that shows Acropora melipora in the 3D display, moreover user can see and listen to the information of these coral species through sound and text. The figure below shows the page of Acropora melipora. 


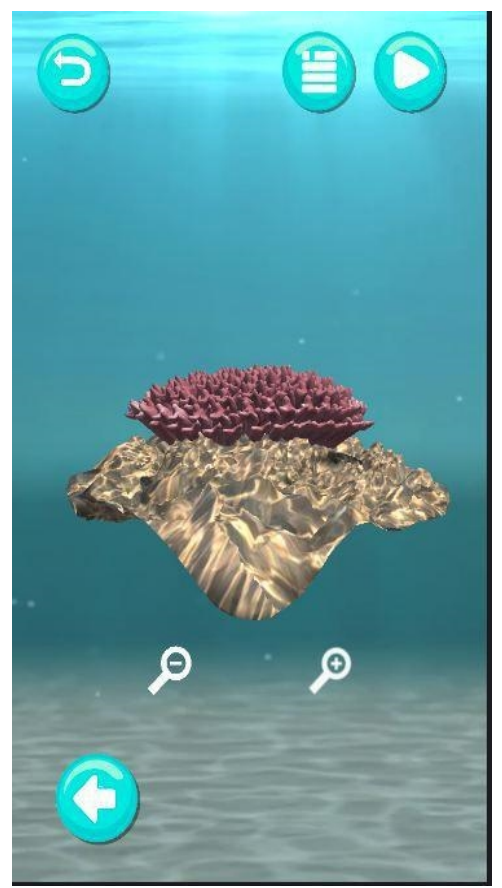

Fig.9. Display of Acropora melipora page

\section{Conclusion and suggestion}

\subsection{Conclusion}

The introduction of coral reef species using 3D display has applied in android mobile. This application does help for the people who wants to know and learn about the kinds of coral reef in Indonesia. It can increase the knowledge and perception of the species of coral reef. For subsequent research we suggest that this application have information based on the database so new information about species of coral reef can be added into application easily.

\subsection{Suggestion}

The suggestions from this research are as follows:

1. This application could be equipped with a database

2. This application could be equipped with a pattern recognition feature

Acknowledgements. Thank you to everyone involved in the process of making this research and its support so that research can be completed.

\section{References}

[1] Ridwan Lasabuda: Pembangunan Wilayah Pesisir Dan Lautan Dalam Perspektif Negara Kepulauan Republik Indonesia.Jurnal Ilmiah Platax, Vol. I-2, pp. 92-101, 2013. 
[2] Wilda Yuliani, M. Ali. S, Mimie saputri.: Pengelolaan Ekosistem Terumbu Karang Oleh masyarakat di Kawasan lhokseudu Kecamatan Leupung kabupaten Aceh Besar. Jurnal Ilmiah MahasiswaPendidikan Biologi,Volume1, Issue 1, pp.1-9, 2016.

[3] Unstain NWJ Rembet.: Simbiosis Zooxanthellae dan Karang Sebagai Indikator Kualitas Ekosistem Terumbu Karang. Jurnal Ilmiah Platax. Vol. I-1, pp .37-44, 2012.

[4] Rethyany Putri, Elsa.: Aplikasi Pembelajaran Ensiklopedia Ekosistem Terumbu Karang Berbasis Multimedia. Other thesis, UPN "VETERAN" YOGYAKARTA, 2014.

[5] Ilham B Mataburu.: Identifikasi Kondisi Terumbu Karang Perairan Bagian Selatan Pulau Sepanjang, Kabupaten Sumenep Dengan Menggunakan Citra Landsat 8. Jurnal SPATIAL - Wahana Komunikasi dan Informasi Geografi, Volume 13 Nomor 1, 2015.

[6] Aziz Salam, Dodo Sahputra, dan Veggy Arman.: Kerusakan Karang di Perairan Pantai Molotabu Provinsi Gorontalo. Jurnal Ilmiah Perikanan dan Kelautan. Volume 1, Nomor 1, 2013. 